\title{
THE EFFECT OF MATING UPON LH RELEASE IN MALE AND FEMALE VOLES OF THE SPECIES MICROTUS AGRESTIS
}

\author{
H. M. CHARLTON, F. NAFTOLIN, ${ }^{*}$ M. G. SOOD \\ AND R. W. WORTH \\ Department of Human Anatomy, South Parks Road, Oxford
}

(Received 13th Fuly 1974)

Members of the microtine species are probably reflex ovulators. The prairie vole, Microtus ochrogaster (Richmond \& Conway, 1969), the meadow vole, $M$. pennsylvanicus (Clulow \& Mallory, 1970), the levant vole, M. guentheri (Bodenheimer \& Sulman, 1946), the Galifornian vole, M. californicus (Greenwald, 1956), and the montane vole, Microtus montanus (Gray, Davis, Zerylnick \& Dewsbury, 1974) have all been regarded as coming into this category and Breed (1967) has demonstrated that members of $M$. agrestis are also reflex ovulators.

As ovulation is normally preceded by a surge of LH in the blood, post-coital levels of serum LH were measured by radioimmunoassay in female and male voles $(M$. agrestis) after mating. The method used was that described by Niswender, Midgley, Monroe \& Reichert (1968) for rat LH, as modified by Naftolin \& Corker (1971).

The voles in these experiments were sexually mature adults from the Departmental colony. The females weighed approximately $20 \mathrm{~g}$, and the males about $25 \mathrm{~g}$. Matings took place in circular glass troughs $20 \mathrm{~cm}$ in diameter, and 10 $\mathrm{cm}$ deep. These were covered with wooden lids equipped with ventilation holes. A 'successful mating' involved lordosis in the female, intromission by the male, and the subsequent presence of a seminal plug in the vagina.

Males and females were bled, at various times, from the sub-orbital canthal sinus under light ether anaesthesia. No blood samples were taken before mating because our assay system could not measure with accuracy levels around or below $1.0 \mathrm{ng}$ NIH-LH-S13/ml.

Although females with moist patent vaginae were used in these experiments, the incidence of successful matings was only about $60 \%$, and a rise in serum LH levels was only detected in those females in which lordosis occurred and a vaginal plug was found after mating. In all other females, even though the male may have attempted to mount several times over a period of $15 \mathrm{~min}$, the serum LH remained low.

The first blood samples were taken within 5 min of a successful mating and high levels of $\mathrm{LH}$ were recorded at this time, with a mean of $61 \cdot 0 \pm 5 \cdot 7$ ng NIH-LH-S13/ml (number of samples $=20$ ). There was a progressive

\footnotetext{
* Present address: Department of Obstetrics and Gynecology, Harvard Medical School, Boston, Massachusetts 02115, U.S.A.
} 
decline in the serum content of LH over the next $2 \mathrm{hr}$, by which time values were nearly back to pre-coital resting levels. When it was possible to obtain several successive blood samples from the same animal, rises of LH were associated with the presence of corpora lutea $24 \mathrm{hr}$ later.

A further experiment was undertaken to investigate the effects on serum $\mathrm{LH}$ of returning the female to the male $90 \mathrm{~min}$ after an initial mating. A second rise in $\mathrm{LH}$ was seen in all eight females used in this experiment. A typical example is shown in Text-fig. 1 .

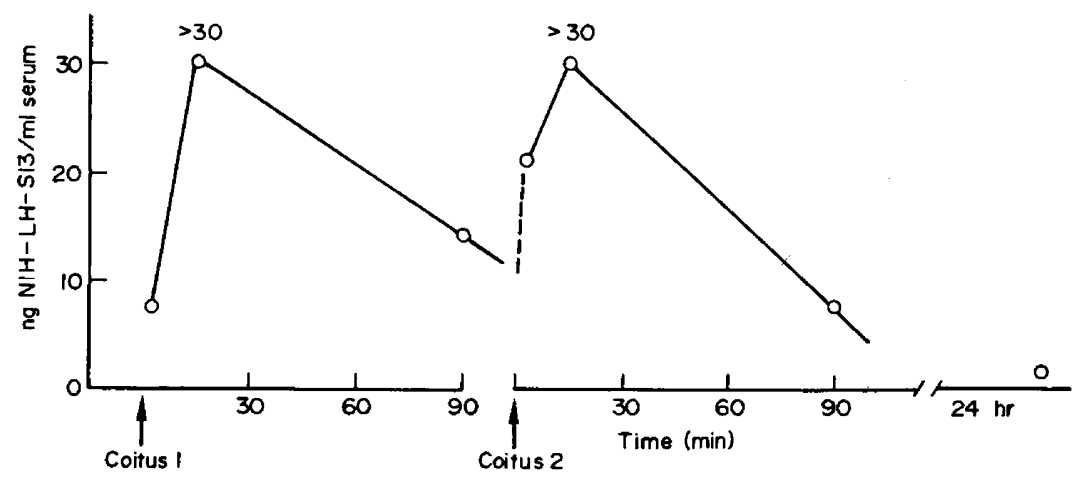

TExT-Fig. 1. Serum LH profile recorded in a female vole (M. agrestis) after a first intromission, followed by a second mating $90 \mathrm{~min}$ later.

In a final experiment, eleven females with the vagina taped over were introduced to males. Although lordosis was observed, the LH values did not rise above basal levels in any of the females. In a recent study, however, Milligan (1975) found evidence of ovulation in three out of eleven 'taped' females.

Attempts to induce ovulation and associated increases in serum $\mathrm{LH}$ by stimulation of the cervix using a plastic-covered rod, driven by an electric vibrator, were unsuccessful.

Little attention has been paid to LH secretion in male mammals. Saginor \& Horton (1968) reported a reflex release of gonadotrophins associated with an increase in plasma testosterone after copulation in the rabbit. Katongole, Naftolin \& Short (1971) demonstrated a rapid rise in blood levels of LH after teasing and ejaculation in the bull, but this was not confirmed by the study of Convey, Bretschneider, Hafs \& Oxender (1971).

In male rats, Taleisnik, Caligaris \& Astrada (1966), using the Parlow assay on pooled samples of plasma, found that LH levels increased significantly 5 to $10 \mathrm{~min}$ after mating. Davidson, Smith \& Bowers (1973), however, referred to unpublished work which indicated that there was no change in the plasma LH detectable by radioimmunoassay after mating in male rats of the Wistar and Long-Evans strains.

Purvis \& Haynes (1974) have shown that testosterone levels are raised within 5 to $10 \mathrm{~min}$ after copulation in the rat, even in males placed in close proximity to oestrous females but not allowed physical contact. This rapid rise in testosterone is thought to be gonadotrophin-independent.

Such a brief review indicates the relative paucity of evidence that mating reflexly releases $\mathrm{LH}$ in the male, and also that results are conflicting. 
Since removal of males from the animal house and placing them in a strange environment might cause a release of $\mathrm{LH}$, a control group of males was brought from the animal house and left in the breeding troughs for $30 \mathrm{~min}$. Blood samples for assay were taken at 5 and $30 \mathrm{~min}$. No rise in $\mathrm{LH}$ above resting levels occurred in any of the twelve animals in this group at either time interval. In a second experiment, males were bled between 5 and 15 min following a 'successful mating'. Of twenty-nine animals, twenty-one showed an elevated level of serum LH ranging from 5 to $20 \mathrm{ng}$ NIH-LH-S $13 / \mathrm{ml}$ with a mean \pm S.E. of $10 \cdot 3 \pm 5 \cdot 0$. The remaining eight animals showed no rise above the normal basal level of $<1 \mathrm{mg}$ NIH-LH-S13/ml. In a further experiment, twenty-seven males which attempted to mate with non-receptive females were bled between 15 and $30 \mathrm{~min}$ after introduction of the female. Eleven failed to show any elevation in serum LH but, in the remaining sixteen, a rise of between 3.0 and $22 \mathrm{ng} \mathrm{NIH-LH-S13/ml} \mathrm{occurred,} \mathrm{with} \mathrm{a} \mathrm{mean} \mathrm{of} 7 \cdot 4 \pm 4 \cdot 3$.

A final group of males was tested, this time after attempted matings with sexually receptive females, but with the vagina taped over. Of the eleven animals in this group, five failed to show any rise in serum LH after $15 \mathrm{~min}$ of attempting to mate, and in the remaining six increases ranging from 2.5 to $11 \mathrm{ng} \mathrm{NIH-LH-S13/ml} \mathrm{occurred,} \mathrm{with} \mathrm{a} \mathrm{mean} \mathrm{of} \mathrm{7.02} \pm 4 \cdot 0$.

It is obvious that male and female voles differ in their response to a mating stimulus. In females, evidence of a reflex rise in LH has only been detected after successful intromission. Milligan (1974) has, however, demonstrated the presence of corpora lutea in oestrous voles kept in close proximity to, but separated from, adult males. Likewise, Gray et al. (1974) have found ovulation occurring occasionally in situations in which the male has been separated from the female. In both of these cases, the evidence of ovulation having occurred was based upon histological examination at a later date. Because the half-life of LH is so short (levels return to a base line in approximately $2 \mathrm{hr}$ ), and because samples were taken within $30 \mathrm{~min}$ of introduction of the male, it is probable that any surge which might have occurred later due to some other influence, for example pheromones or altrasonic vocalization, would have been missed.

It is tentatively concluded that some aspects of the mating situation can elicit a reflex release of $\mathrm{LH}$ in male voles, but the magnitude of this response is much less than in females, and it does not depend entirely upon coitus for its initiation.

This work was supported by grants from the Medical Research Council. The help of Mrs Jeannie Mattock, Miss Shirley May, Mr R. J. Rees, and Mr R. W. Laynes is greatly appreciated.

\section{REFERENCES}

Bodenheimer, F. S. \& Sulman, F. (1946) The estrous cycle of Microtus guentheri and its ecological implications. Ecology, 27, 255-256.

BREed, W. G. (1967) Ovulation in the genus Microtus. Nature, Lond. 214, 826.

Glulow, F. V. \& Mallory, F. F. (1970) Oestrus and induced ovulation in the meadow vole, Microtus pennsylvanicus. F. Reprod. Fert. 23, 341-343. 
Convey, E. M., Bretschneider, E., Hafs, H. D. \& Oxender, W. D. (1971) Serum levels of LH, prolactin and growth hormone after ejaculation in bulls. Biol. Reprod. 5, 20-24.

Davidson, J. M., SmITh, E. R. \& Bowers, C. Y. (1973) Effects of mating on gonadotrophin release in the female rat. Endocrinology, 93, 1185-1192.

Gray, G. D., Davis, H. N., Zerylnick, M. \& Dewsbury, D. A. (1974) Oestrus and induced ovulation in montane voles. 7. Reprod. Fert. 38, 193-196.

Greenwald, G. S. (1956) The reproductive cycle of the field mouse, Microtus californicus. F. Mammal. 37, 213-222.

Katongole, C. B., Naftolin, F. \& Short, R. V. (1971) Relationship between blood levels of luteinizing hormone and testosterone in bulls and the effects of social stimulation. 7 . Endocr. 50, 457-466.

Milligan, S. (1974) Social environment and ovulation in the vole, Microtus agrestis. J. Reprod. Fert. 41, 35-47.

Milligan, S. (1975) Mating, ovulation and corpus luteum function in the vole, Microtus agrestis. $\mathcal{7}$. Reprod. Fert. 42, 35-44.

Naftolin, F. \& CoRkER, C. S. (1971) An ultramicro method for the measurement of luteinising hormone by radioimmunoassay. In Radioimmunoassay Methods, p. 641. Eds. K. E. Kirkham and W. H. Hunter. Churchill, London.

Niswender, G. D., Midgley, A. R., JR, Monroe, S. E. \& Reichert, L. E., JR (1968) Radioimmunoassay for rat luteinising hormone with antiovine LH serum and ovine LH- ${ }^{131} \mathrm{I}$. Proc. Soc. exp. Biol. Med. 128, 807-811.

Purvis, K. \& Haynes, N. B. (1974) Short-term effects of copulation, human chorionic gonadotrophin injection and non-tactile association with a female on testosterone levels in the male rat. $\mathcal{F}$. Endocr. 60, 429-439.

Richmond, M. \& Conaway, C. H. (1969) Induced ovulation and oestrus in Microtus ochrogaster. $\mathcal{J}$. Reprod. Fert., Suppl. 6, 357-376.

SAGinor, M. \& Horton, R. (1968) Reflex release of gonadotropin and increased plasma testosterone concentration in male rabbits during copulation. Endocrinology, 82, 627-630.

Taleisnik, S., Caligaris, L. \& Astrada, J. J. (1966) Effects of copulation on the release of pituitary gonadotropins in male and female rats. Endocrinology, 79, 49-54. 